\title{
THE IMPACTS OF MACROECONOMIC VARIABLES ON WELFARE IN THE SULTANATE OF OMAN
}

\author{
Juma Alyazeedi and Dr. Gholamreza Chabokrow \\ Department of Economics and Finance, College of Economics, Management and Information Systems, \\ University of Nizwa, Sultanate of Oman
}

DOI: 10.46609/IJSSER.2020.v05i11.006 URL: https://doi.org/10.46609/IJSSER.2020.v05i11.006

\begin{abstract}
This paper investigates how Oman's welfare and the citizens' wellbeing is affected by macroeconomic variables. In this study the impacts of inflation, wages, unemployment and openness of welfare - GDP per capita (current local currency)- in Oman are estimated using the Pearson correlation coefficient to find the nature of the relationship between them. Gini index was added to see if it has any impact on the welfare. The study showed that Inflation, wages and openness positively and directly affect welfare with over $90 \%$ correlation for wages and openness. Unemployment showed a negative relationship with the same variables. Policy makers, in their pursuit of increasing Omani welfare and the level of citizens' wellbeing, should focus more on reducing the unemployment rate rather than on restraining inflation and give more freedom for international trade (which may create more jobs and might lead to an increase in wages).
\end{abstract}

\section{INTRODUCTION}

This study addresses the issue of the cyclical relationship between welfare level as a dependent variable and macroeconomic independent variables such as wages, unemployment, and inflation, as well as the long-term association between welfare, growth, and inequality. It also examines the relationship between welfare and growth as asymmetrical, whether it varies by level of development, and whether it differs by policy context, where structural reforms undertaken in Oman during last decades are taken as a case in point. The analysis benefits from a variety of welfare conceptions, primary source measures, and a great deal of variation in all variables, to date only found in a cross-country context. Conclusion of this project will help government to apply policies for increasing the prosperity of households in rural and urban areas of the Sultanate of Oman.

Previous studies indicate that an evaluation of the effect of macroeconomic variables on welfare 


\section{International Journal of Social Science and Economic Research}

ISSN: $2455-8834$

Volume:05, Issue:11 "November 2020"

reveals that unemployment rate, inflation rate and Gini coefficient variables have an adverse relation to the cardinal welfare in both Pareto and non-Pareto cases, while the literacy rate and government expenditures have a positive relation to the welfare index. The findings also imply that there is a positive relationship between economic growth and welfare level in Iran (Tash, Molaei \& Kamran, 2017).

The multidimensional poverty concept is relevant for assessing deprivation in developed countries and, in line with the relevant literature, the dynamics of some macroeconomic variables are crucial to deprivation performances. The latter result is robust as it holds for different measures of poverty.

It is believed that the level of poverty is significantly determined by macroeconomics variables such as inflation, government expenditure and unemployment rate. In addition, there is a negative relation between poverty and growth, Unemployment and inflation have positive effects on poverty, while social security expenditure relating to government expenditure has no meaningful effects on poverty (Farhad \& Nabi, 2014).

Is unemployment costlier than inflation? Our answer seems to be "yes" (Blanchflower, et al, 2014). Unemployment is a bad thing. It is bad for the economy and for society, for unemployed people themselves, for their families and for the communities in which they live (Peter Saunders, 2002). The relationship between unemployment and (income) inequality cannot be assumed to automatically exist (Peter Saunders, 2002). The relationship between poverty and unemployment has been seemingly unclear, since being unemployed usually results in a fall in one's living standard due to the absence of income, and it is also possible for one to be employed and still be poor. Even with the policy of unemployment reduction and poverty alleviation being the core goals in many developing countries, attaining these objectives has been relatively defeated with the high incidence of both poverty and unemployment (Agenor, 2004). Being employed does not guarantee the escape from poverty (Ryscayage, 1982).

Inflation is usually measured using the idea of a price index. The consumer price index (CPI) is the most frequently used measure of inflation and cost of living. The CPI measures the change in the average price of fixed goods or package of consumer goods and services from the base year to the year in which the change is to be measured (Mariam Alubaid, 2008). Inflation lowers the value of the currency and thus raises the poverty line, which contributes to the increase in the number of poor in the country, which in turn contributes to reducing the skills and abilities of young people to contribute to economic development

An increase in trade openness may be detrimental to economic growth by increasing inflation and lowering exchange rates (Cooke, 2010; Jafari Samimi et al., 2012). Trade openness may impact 


\section{International Journal of Social Science and Economic Research}

ISSN: $2455-8834$

Volume:05, Issue:11 "November 2020"

economic growth negatively for countries which specialize in production of low-quality products (Haussmann, Hwang, \& Rodrik, 2007). Trade liberalization encourages specialization in sectors which have economies of scale that contribute to improving the efficiency and productivity in the long-run (Krueger, 1978; Bhagwati, 1978).

\section{METHODOLOGY}

This part is concerned with the research methodology followed in this study. More specifically, it casts light on the research method, data collection, criteria for selecting the data sample, and procedure of collecting data. Taking into account that the terms "methodology" and "method" are

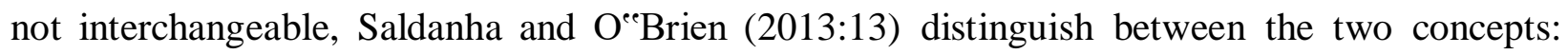
"methodology is a general approach to studying a phenomenon whereas a method is a specific research technique". To put it differently, while the former refers to the systematic analysis of the methods applied to find out knowledge, the latter refers to the tools, techniques and data analysis, i.e., a qualitative method and quantitative method, or even the combination of both, are examples of methods.

In this study, the relation between macro variables and the welfare level was investigated through an econometric model. In line with achieving this goal, two main test have been applied. First, the Pearson correlation coefficient has been applied to find the nature of the relationship between the dependent variables (Welfare) and the independent variables (Wage rate, Unemployment rate, Inflation rate and Openness rate) and Analysis of variance (ANOVA) for the dependent variable (welfare) regression in predicting Wage rate, Unemployment rate, Inflation rate and Openness rate. In this research, the variables of inflation rate, unemployment rate and wage rate during recent decades are considered as determinants of welfare level. Since theory offers little guidance in the construction of a structural system, the research chooses a reduced-form specification in the tradition of that employed in the literature where focus is on what a long span of comparable and high-quality data says through the use of appropriate estimation techniques.

The statistical information related to mentioned variables and also the price index and Gini coefficient are obtained from Central Bank of Oman. In order to study the effect of macro variables on welfare in Oman, the following regression has been considered:

$D \operatorname{Ln}(W e l) t=a+\beta_{1} D \operatorname{Ln}($ Wage $) t+\beta_{2} D \operatorname{Ln}($ Unemp $)+\beta_{3} D \operatorname{Ln}(\operatorname{Infl})+\beta_{4} D \operatorname{Ln}($ Open $)+e t$

in which Wage is the wage rate, Unemp is unemployment rate, Infl is the inflation rate, Open is the Openness rate and $\mathrm{Wel}$ shows the welfare Index. $L n$ indicates logarithm, $D$ shows the reduced form, and et is considered as error terms. 
International Journal of Social Science and Economic Research

ISSN: 2455-8834

Volume:05, Issue:11 "November 2020"

Data has been collected from several reliable sources that are concerned mainly with gathering countries' economics data, such as the World Bank site. The World Bank collection of development indicators is compiled from officially recognized international sources. It presents the most current and accurate global development data available, and includes national, regional and global estimates. The information gathered were starting from 1998 to 2018 for most variables.

Another main resource was the National Center for Statistics and Information - Data portal(NCSI). It is a free data-sharing portal where anyone can access data relating to the Sultanate of Oman. The Data Portal provides many datasets from different entities, for everyone - citizen, investor, researcher or developer. Most of the related specific date were from these two websites.

\section{RESULT AND DICCUSSION}

The results of testing the study hypotheses: The Pearson correlation coefficient has been applied to find the nature of the relationship between the dependent variables (Welfare) and the independent variables (Wage rate, Unemployment rate, Inflation rate and Openness rate).

Table 1: Pearson Correlation between welfare (dependent) and wage rate, unemployment, inflation, openness(independent).

\begin{tabular}{|c|c|c|r|}
\hline $\begin{array}{c}\text { wetfare } \\
\text { Independent } \\
\text { variables }\end{array}$ & $\mathrm{N}$ & Sig. (2-tailed) & Pearson Correlation \\
\hline Inflation & 24 & 0.001 & $0.639 * *$ \\
\hline Unemployment & 24 & 0.003 & $-0.577 * *$ \\
\hline Openness & 24 & 0.000 & $0.807 * *$ \\
\hline Wages & 24 & 0.000 & $0.910^{* *}$ \\
\hline
\end{tabular}

Table 1 shows the existence of a statistically significant positive correlation (Sig. (2- tailed)) between welfare and inflation, with the Pearson correlation coefficient of $\mathrm{R}=0.639 * *$, and the existence of a statistically significant negative correlation between welfare and unemployment, where the Pearson correlation coefficient reached $\mathrm{R}=-0.577 * *$. There is a statistically significant positive direct correlation between welfare and Openness, where the Pearson correlation coefficient reached $\mathrm{R}=0.807^{* *}$, and the presence of a statistically significant direct correlation relationship between welfare and Wages with Pearson's correlation coefficient of $\mathrm{R}=0.910 * *$.

How much did welfare contribute to predicting Wage rate, Unemployment rate, inflation rate and 
Openness rate?

To answer the question, Simple linear regression analysis was used to see the extent to which welfare contributed to predicting Wage rate, Unemployment rate, Inflation rate and Openness rate.

Table 2: Analysis of variance (ANOVA) for a variable (welfare) regression in predicting Wage rate, Unemployment rate, Inflation rate and Openness rate.

\begin{tabular}{ccccccc}
\hline $\begin{array}{c}\text { Dependent } \\
\text { variables }\end{array}$ & & Sum of Squares & Df & Mean Square & F & Sig. \\
\hline \multirow{2}{*}{ welfare } & Regression & 100073698.119 & 4 & 25018424.530 & & \\
& Residual & 4728693.172 & 19 & 248878.588 & 100.525 & .000 \\
& Total & 104802391.291 & 23 & & & \\
\hline
\end{tabular}

From the previous table it becomes clear that there is a statistically significant effect (Sig.) of the welfare variable in predicting the level of Wage rate, Unemploymentrate, Inflation rate and Openness rate. Significant at $\alpha=0.05$.

Table 3: Results of the welfare correlation factor in predicting Wage rate, Unemployment rate, Inflation rate and Openness rate.

\begin{tabular}{|c|c|c|c|c|}
\hline $\begin{array}{c}\text { Dependent } \\
\text { Variables }\end{array}$ & $\mathrm{R}$ & $\begin{array}{c}\mathrm{R} \\
\text { Square }\end{array}$ & Adjusted R Square & $\begin{array}{c}\text { Std. Error of } \\
\text { the Estimate }\end{array}$ \\
\hline Welfare & .977 & .955 & .945 & 498.87733 \\
\hline
\end{tabular}

From the table, it is possible to know what is explained by the welfare variable as a whole in predicting the level of Wage rate, Unemployment rate, Inflation rate and Openness rate, with the correlation coefficient $\mathrm{R}$ reaching 0.977 , while the square of the correlation coefficient is $\mathrm{R}^{2}=0.955$. That is, with $(95.5 \%)$, for Wage rate, Unemployment rate, Inflation rate and Openness rate.

Table 4: Simple linear regression variance analysis of the prediction

\begin{tabular}{l|l|l|l|l}
\hline & $\begin{array}{l}\text { Unstandardized } \\
\text { Coefficients }\end{array}$ & $\begin{array}{l}\text { Standardized } \\
\text { Coefficients }\end{array}$ & $\mathrm{T}$ & Sig. \\
\hline
\end{tabular}


International Journal of Social Science and Economic Research

ISSN: 2455-8834

Volume:05, Issue:11 "November 2020"

\begin{tabular}{ll|r|r|r|r|r}
\cline { 3 - 6 } Model & & \multicolumn{1}{l|}{ B } & Std. Error & Beta & & \\
\hline & (Constant) & -33389.266 & 5545.177 & & -6.021 & .000 \\
& Inflation & 207.840 & 43.563 & .280 & 4.771 & .000 \\
welfare & Unemployment & 378.219 & 255.276 & .108 & 1.482 & .155 \\
& Openness & 60.343 & 10.580 & .397 & 5.703 & .000 \\
& Wages & 331.382 & 56.287 & .569 & 5.887 & .000 \\
\hline
\end{tabular}

It is clear from the table that the statistical significance (Sig.) in welfare is smaller than the level of significance $(\alpha=0.05)$. This means welfare1 is predictable at Wage rate, Inflation rate and Openness rate.) Except for unemployment being greater than the level of significance $(\alpha=0.05)$, the results also indicate that the value of the beta coefficient (B) was positive in Wage rate, Unemployment rate, Inflation rate and Openness rate.), and this confirms the range of the positive contribution.

\section{Discussion}

At this point, and to make the result clearer and understandable, here is the equation for the dependent variable (welfare):

$D \operatorname{Ln}($ Wel $) t=a+\beta_{1} D \operatorname{Ln}($ Wage $) t+\beta_{2} D \operatorname{Ln}($ Unemp $)+\beta_{3} D \operatorname{Ln}($ Infl $)+\beta_{4} D \operatorname{Ln}($ Open $)+e t$

The analysis showed most of the mentioned independent variables have a positive relationship with the independent variable (Welfare). Openness and Wages have the most impact on Welfare with almost $80 \%$ and $90 \%$ correlation respectively. That mean the increase in salaries over the last 23 years has contributed positively in the level of welfare and the wellbeing of the Omani citizens. Also, the policies that have been adjusted over the last two decades to give the market more freedom and openness had a huge positive impact in the happiness and the level of living in the sultanate. As the share of the international trade contribution increases in the local GDP, welfare has also increased.

Inflation as an indicator of the consumer price appears to have a significant positive relationship with welfare. The increasing inflation rate has always escorted an increase in the welfare level. In 2008 when the inflation rate was at its highest, welfare was also at its highest ever for the same period.

Even though all the independent variables have a significant relationship with welfare, 
unemployment takes a different direction from that of the other variables. It has a negative relationship with Welfare. The increasing unemployment rate leads to a decrease in the welfare level. More jobs mean more satisfaction for the citizens as their capability of fulfilling their needs will be higher, which means an increase in the welfare and well-being level.

The Gini index varies from country to country, and although it might be higher in poor countries and lower in the richest, it does not always have a negative relationship with welfare (Moatsos and Baten, 2014). However, it is a very reliable index that reflects the wealth or income distribution. Here are some of the results that I found about the Gini coefficient in Oman for both Urban and Rural towns from 2006 to 2018 :

Table 5: Oman Gini Index

\begin{tabular}{|c|c|c|}
\hline Year & Urban & Rural \\
\hline $\mathbf{2 0 0 6}$ & 0.3923 & 0.363 \\
\hline $\mathbf{2 0 0 7}$ & 0.3296 & 0.3332 \\
\hline $\mathbf{2 0 0 8}$ & 0.3438 & 0.3272 \\
\hline $\mathbf{2 0 0 9}$ & 0.3302 & 0.3044 \\
\hline $\mathbf{2 0 1 0 - 2 0 1 7}$ & 0.3072 & 0.307 \\
\hline $\mathbf{2 0 1 8}$ & 0.3075 & 0.2856 \\
\hline
\end{tabular}

Table 5 shows that income improved over the years 2006 to 2018. Since the index ranges from 0 (or $0 \%$ ) to 1 (or 100\%), 0 means the distribution of income is perfectly equal and 1 the opposite. Both Urban and Rural have almost the same level of income distribution. Oman holds a comparable an adequate position regarding the equality of income distribution. Unfortunately, there is not much information and data about the Gini index in Oman; therefore, the relationship between it and the welfare level in the country cannot be tested.

\section{CONCLUSION}

Macroeconomics variables' impacts on welfare vary from one variable to another, yet it can be said that all of them (inflation, unemployment, openness, wages) can affect the outcome of welfare in one way or another. When inflation affects welfare positively, welfare increases. That leads to the highest welfare value being reached while the inflation rate was at its highest as well. In 2008 the inflation rate in Oman jumped to almost 13\% and the welfare1 value was around 
International Journal of Social Science and Economic Research

ISSN: 2455-8834

Volume:05, Issue:11 "November 2020"

8,500. It is confirmed with the Unemployment variable which has almost the same impact (58\%) on welfare, yet in a different direction. An increase in the number of jobless people compared to the population will lead to a decrease in the wellbeing and welfare level in the country.

According to numerical evidence and the test that has been run, openness and wages have a very strong impact on welfare ( $80 \%$ and $90 \%$ respectively). With openness and the movement of exports and imports, the level of welfare has increased. Yet there is not enough evidence about the significance of this relationship.

Although wages and welfare from 1995 to 2018 increased together, and the Pearson correlation test shows a strong $90 \%$ relationship, the significance of this relation is not high at all, which makes further study of their connection important.

\section{Recommendations}

- Monitor the unemployment rate and make the most appropriate policy to keep the rate low and controllable.

- Create more job opportunities in both the public and private sectors to reduce the negative impact of the unemployment rate.

- Enhance and prepare the local ports to make them more capable of receiving commercial ships.

- The inflation rate should be focused on so that it will not reach a level where it might hurt the welfare level instead of increasing it.

Enforce the rules regarding wages and make sure that employees receive at least the minimum according to the country's regulations.

\section{REFERENCES}

Agenor, Pierre-Richard. (2004). Unemployment - poverty trade-offs.

Ahn, Namkee \& García, Juan \& Jimeno, Juan. (2004). The Impact of Unemployment on Individual Well-Being in the EU. 29.

Anne O. Krueger, 1978. Foreign Trade Regimes and Economic Development: Liberalization Attempts and Consequences, NBER Books,National Bureau of Economic Research, Inc, number krue78-1, Juni. 


\section{International Journal of Social Science and Economic Research}

ISSN: $2455-8834$

Volume:05, Issue:11 "November 2020"

Bhagwati, Jagdish \& Srinivasan, T. N. (1975). Foreign Trade Regimes and Economic

Development: India. XF2006172468.

Cooke, Dudley. (2010). Openness and Inflation. Journal of Money, Credit and Banking. 42. $267-$ 287. $10.2307 / 20685100$.

Farhad Khodadad Kashi, Mohammad Nabi Shahikitash, (2014). Effects of macroeconomic variables on poverty in Iran (Application of bootstrap technique), Theoretical and Applied Economics, Vol XXI (2014), No. 5(594), pp. 85-96.

Mariam Alobaid, Farima Alramzi (2008). Kuwaiti citizens' priorities. Majlis alumah.

Mohammad Nabi Shahiki Tash, Saber Molaei, Kamran Barghandan, (2017). Evaluating the effect of macroeconomic variables on the welfare changes in Iran, International Journal of Social Economics, Vol. 44 Issue: 5, pp.594-604

Paul M. Ryscavage. (1982). Employment problems and poverty: examining the linkages. Monthly labor review. June 1982

Rodrik, Dani \& Hausmann, Ricardo \& Hwang, Jason. (2007). What You Export Matters. Journal of Economic Growth. 12. 1-25. 10.2139/ssrn.896243.

Samimi, Ahmad \& Ghaderi, Saman \& Hosseinzadeh, Ramezan \& Nademi, Younes. (2012). Openness and Inflation: New Empirical Panel Data Evidence. Economics Letters. 117. 573-577. 10.1016/j.econlet.2012.07.028.

Saunders, Peter. (2002). The Direct and Indirect Effects of Unemployment on Poverty and Inequality. Australian Journal of Labour Economics (AJLE). 5. 507-530. 